\title{
RESPONSE OF THE APODI-MOSSORÓ ESTUARY-INCISED VALLEY SYSTEM (NE BRAZIL) TO SEA-LEVEL FLUCTUATIONS
}

\author{
Helenice Vital $^{1,2 *}$, Samia F.Lima Furtado ${ }^{1,3}$ and Moab Praxedes Gomes ${ }^{1}$ \\ ${ }^{1}$ Universidade Federal do Rio Grande do Norte \\ Programa Pós-Graduação em Geodinâmica e Geofísica, MME-ANP-PRH 22 \\ (Campus, POBOX. 1596, 59072-970 Natal, RN, Brasil) \\ ${ }^{2}$ Pesquisador do Departamento de Geologia \\ Conselho Nacional de Desenvolvimento Científico e Tecnológico - CNPq \\ ${ }^{3}$ PETROBRAS, Petróleo Brasileiro SA, UN-RNCE \\ (Av. Prof. Mor Gouveia, Natal, RN, Brasil) \\ *Author correspoding: helenice@geologia.ufrn.br
}

\begin{abstract}
A B S TRACT
This study focuses on the Quaternary sea level changes in the Apodi-Mossoró Estuary and adjacent shelf, Northeastern Brazil, based on the analysis of high-resolution seismic profiles, integrated with echosounder, SRTM and satellite image data. We use these data to develop a relative stratigraphy. An incised-valley extending from the Apodi-Mossoró Estuary onto the shelf dominates the investigated area. In very shallow waters (down to $10 \mathrm{~m}$ depth) the channel lies mainly in a NW-SE direction, changing to NE-SW in waters below $10 \mathrm{~m}$, in the form of a $\mathrm{J}$-shaped valley. The southern flank of the shallow channel presents an abrupt morphology, probably determined by a residual scarp due to neotectonic reactivation of a pre-existing fault. This incised-valley can be correlated with a former river valley formed during the late Pleistocene fall in sea-level. The base-level change related to this drop in sea level can be regionally expressed on seismic lines as a laterally-continuous stratigraphic surface named Horizon I, interpreted as representing the sub-aerial exposure of the continental shelf. Many incised valleys were excavated on this exposed shelf, including that of the Apodi-Mossoró Estuary and its incised valley system. This incised valley has lain buried since the Holocene transgression. The Holocene sediments present sub-horizontal layers, or they have filled the incised valley with oblique features.
\end{abstract}

\section{RESUMO}

Este estudo utiliza a integração de dados sísmicos de alta resolução, batimétricos, SRTM e imagens de satélite para desenvolvimento da estratigrafia relativa visando entender as variações do nível do mar durante o Quaternário no estuário do rio Apodi-Mossoró e plataforma adjacente, nordeste do Brasil. A principal feição identificada foi um canal submerso, na plataforma interna, parcialmente preenchido, provavelmente relacionado com o sistema de vales incisos formado durante o rebaixamento do nível do mar no Pleistoceno. O canal apresenta duas direções principais (NW-SE e NE-SW), em forma da letra J, aparentemente controladas pelas estruturas tectônicas da Bacia Potiguar. A margem oeste do canal é relativamente soerguida em relação à margem leste. Com base nos dados sísmicos foi possível identificar uma descontinuidade presente em toda a área, interpretada como o limite Pleistoceno/Holoceno, bem como sismofácies referentes a padrões de preenchimento e sedimentação do canal submerso e da plataforma durante a subida do nível do mar no Holoceno.

Descriptors: NE Brazilian shelf; Mossoró-Apodi Estuary, Incised valley, Sea-level changes, Seismostratigraphy.

Descritores: Plataforma NE Brasileira, Estuário Apodi-Mossoró, Vales inciso, Mudanças do nível do mar, Sismoestratigrafia.

\section{INTRODUCTION}

Estuaries and incised valleys and their preserved deposits are important depositional settings that have widespread significance as the sites of human habitation, as harbors, as the host of significant hydrocarbon reserves, and as the repository of important information on lowstand to early transgressive sedimentation in ramp and shelf settings (e.g., BOYD et al., 2006; DALRYMPLE et al., 1994, 2006). They also contain valuable information on regional depositional processes and sea level changes (e.g., LI et al., 2006). The development of ideas on incised valleys is not new, going back to Greek and 
Roman times (BOYD et al., 2006). However, the interest in incised valley studies has increased since the appearance of SEPM Special Publication 51 in 1994. More recently, Boyd et al. (2006) based on recent advances in estuarine and incised valley models have delineated the elements which represent important components of such facies models for the twenty-first century: 1) precise definition of the estuarine and incised valley system and its morphological elements; 2) quantitative database of the geometry and facies of entire systems from many global examples, both ancient and modern; 3) main processes operating in the system; 4) sediments-input component; 5) computer-modeling software to simulate the process identified; and 6) model output evaluated on how well it reproduced field-type examples.

Additionally, the lack of any high resolution stratigraphic and geomorphic data for very shallow waters has limited the success of attempts to unravel the stratigraphic record of the estuaries and shelf margin.

Although numerous studies of Quaternary (2.6 My to present) incised valleys from around the world, most of them were carried out at high latitudes, have been made, few previous studies have dealt with the Holocene (since11,500 B.P.) development of the northeastern Brazilian coast and shelf (PESSOA NETO, 1999, 2003; SCHWARZER et al., 2006; LIMA; VITAL, 2006).
In an attempt to represent the effects of the latest Pleistocene-Holocene regression and transgression preserved in seafloor bedforms and shallow subsurface deposits of estuarine incisedvalleys we present new data from the tropical Brazilian shelf.

Our approach involves geomorphic analysis based on remote-sensing images and digital elevation models, coupled with seismic stratigraphic analyses. Using these data, we develop a stratigraphic interpretation, and discuss the dynamic processes, including sea-level changes, that created and modified observed bedforms and Quaternary stratigraphy. Insights gained from studying stratigraphic and geomorphic responses to base-level fluctuations are valuable as part of a larger effort to understand the effects of sea-level variations on mixed siliciclasticcarbonate, sediment starved continental margins like that of northeastern Brazil.

The aim of this paper, therefore, is to describe the Apodi-Mossoró estuarine and incised valley of the northeastern Brazilian margin (Fig. 1), and so to contribute to the development of models for tropical estuary and incised-valley depositional systems. Moreover, this study constitutes a step toward correlating modern processes with processed-based features inferred from the preserved geological record, as well as enabling these data to be used as analogs for high-energy mixed siliciclastic-carbonate shelves and shelf sequences.

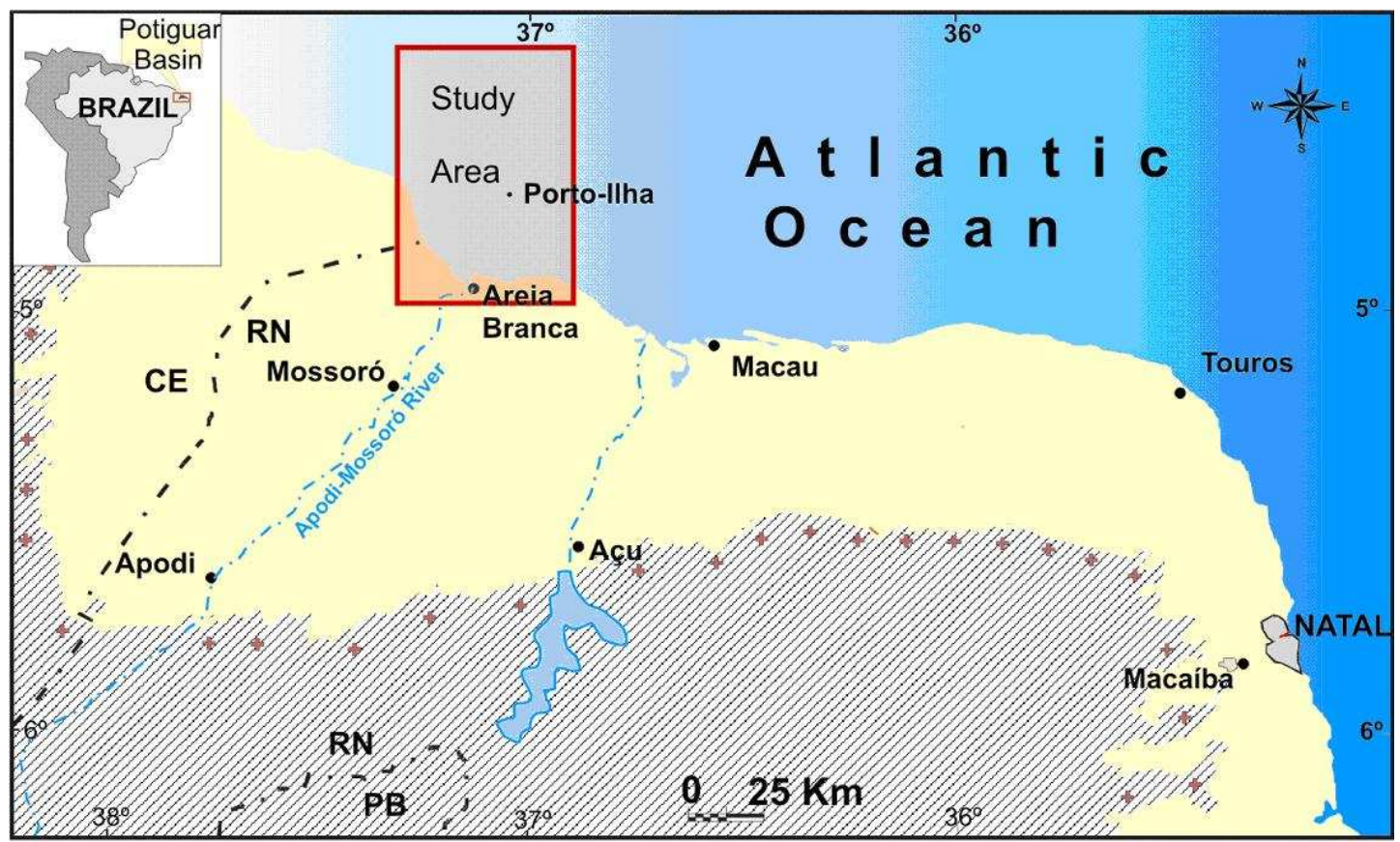

Fig. 1. Location of the study area. 


\section{Methods}

An operational methodology was developed using remote-sensing images (Landsat), SRTM data and geographical information systems (GIS). This was used to provide an overview of the area and for planning the acquisition of the hydroacoustic data. Due to the complexity of the features on the NE Brazilian shelf, a range of digital image processing techniques were used and compared (e.g. Multitemporal Image Analysis, Water Index, Principal Component Analysis - PCA, and Adaptive Filtering $3 \times 3$ and $5 \times 5$ convolution). Nevertheless, the clear waters of the northeastern Brazilian margin, resulting from the dry climate and minimal organic turbidity, favor the employment of satellite images. The satellite images used in this research comprise a LANDSAT 7 ETM+, path-row 216_063 (13/08/1999 and 20/07/2002) and 215_063 (13/06/2000). They were georeferenced by the UTM coordinate system and processed by RGB 123 color composition.
The hydroacoustic data were collected perpendicular to the coast, producing a total of 31 profiles $(\sim 850 \mathrm{~km})$ within a grid of $1 \mathrm{~km}$ spaced lines. They were collected using an Odom Hydrographic Systems HYDROTRAC echosounder, operating on the $200 \mathrm{kHz}$ frequency. Post-collection processing of data consisted of the filtering of the data and the elaboration of the digital terrain model, using the kriging method for the interpolation (Figs 2 and 3).

The depositional shelf dynamics and stratigraphic evolution of the sandy, estuary-mouth deposits of mixed-energy (wave and tide) estuaries along the northern coast of Brazil were also taken into account. The hydrodynamic data were collected at the same time as the bathymetric data. The equipment used was an InterOcean currentmeter model S4. It was installed on the western side of the main channel, at half-water level $(\sim 8 \mathrm{~m})$, to measure the intensity and direction of the current in the region. The average level of tides recorded by the current meter was used in the correction of the bathymetric data.

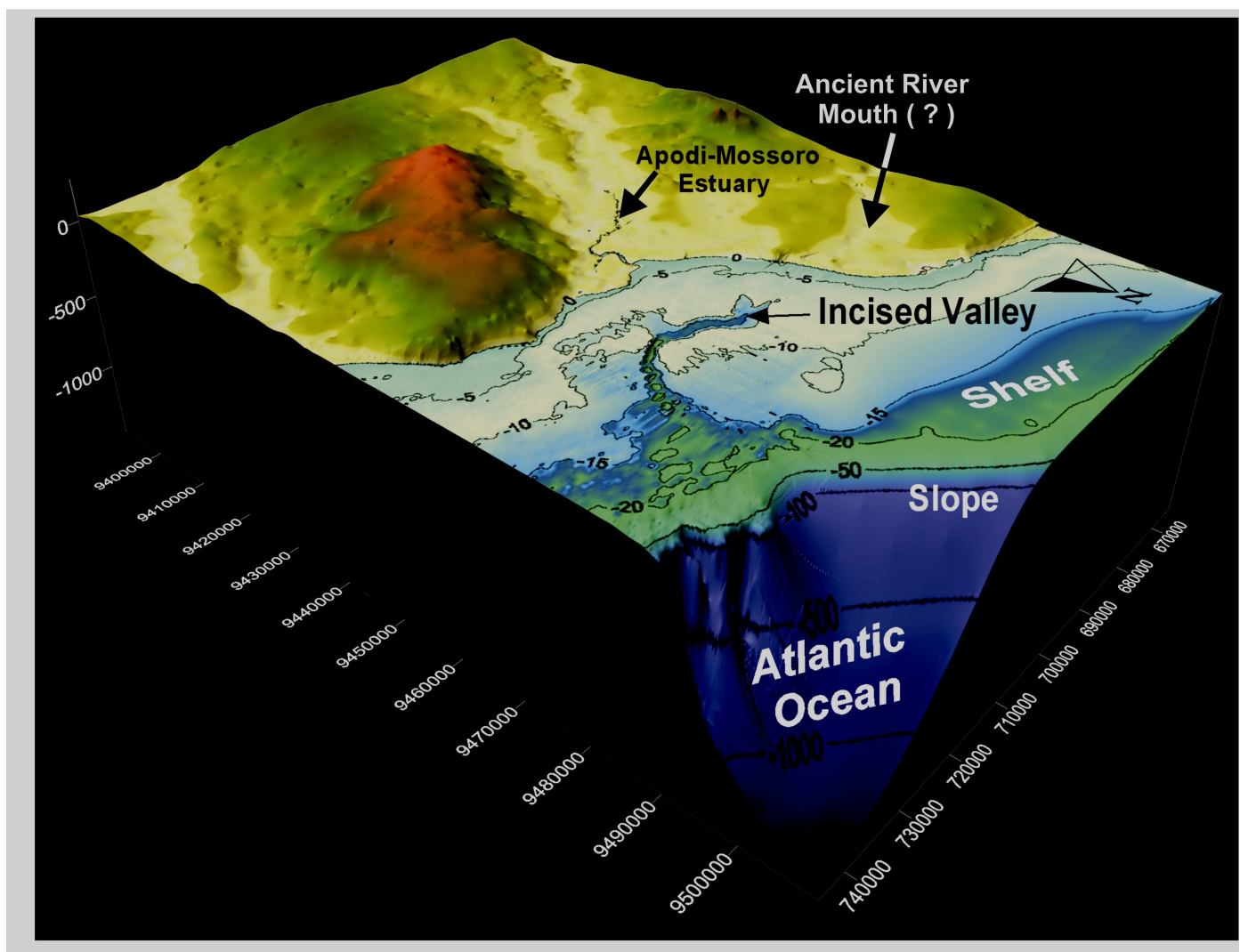

Fig. 2. View of Apodi-Mossoró Estuary \& incised-valley on the NE Brazilian shelf. Terrain Digital Model constructed with SRTM data (land) and echosounder dataset (shelf). The Apodi-Mossoró canyon terminates at the shelf break. The paleoriver mouth was probably situated westwards of the present Apodi-Mossoró Estuary. 
The seismic and sonographic data were collected using an EdgeTech subbottom discover type X-Star 3200-XS (bandwidth $0.5-6 \mathrm{~Hz}$ ) and a side scan sonar type 272-TD, respectively. The seismic profiles were distributed along the main channel and on its margins, totaling 9 profiles $(\sim 136 \mathrm{~km})$. The sonographic data were collected along one of the main profiles $(\sim 9 \mathrm{~km})$. The post-collection processing of the seismic and sonographic data consisted of contrast enhancement, filtering and the application of time variable gain (TVG).
Sediment samples were collected using a Van Veen bottomgrab and by scuba diving. Sample preparation for the sedimentological analyses involved the standard procedures already described in the literature (e.g., LORING; RANTALA, 1992).

These integrated datasets were collected to examine the continuation of the Apodi-Mossoró valley onto the adjacent modern continental shelf and the response of fluvial systems to sea-level fluctuations. The location of the profiles referred to in this article may be seen in Figure 3 .

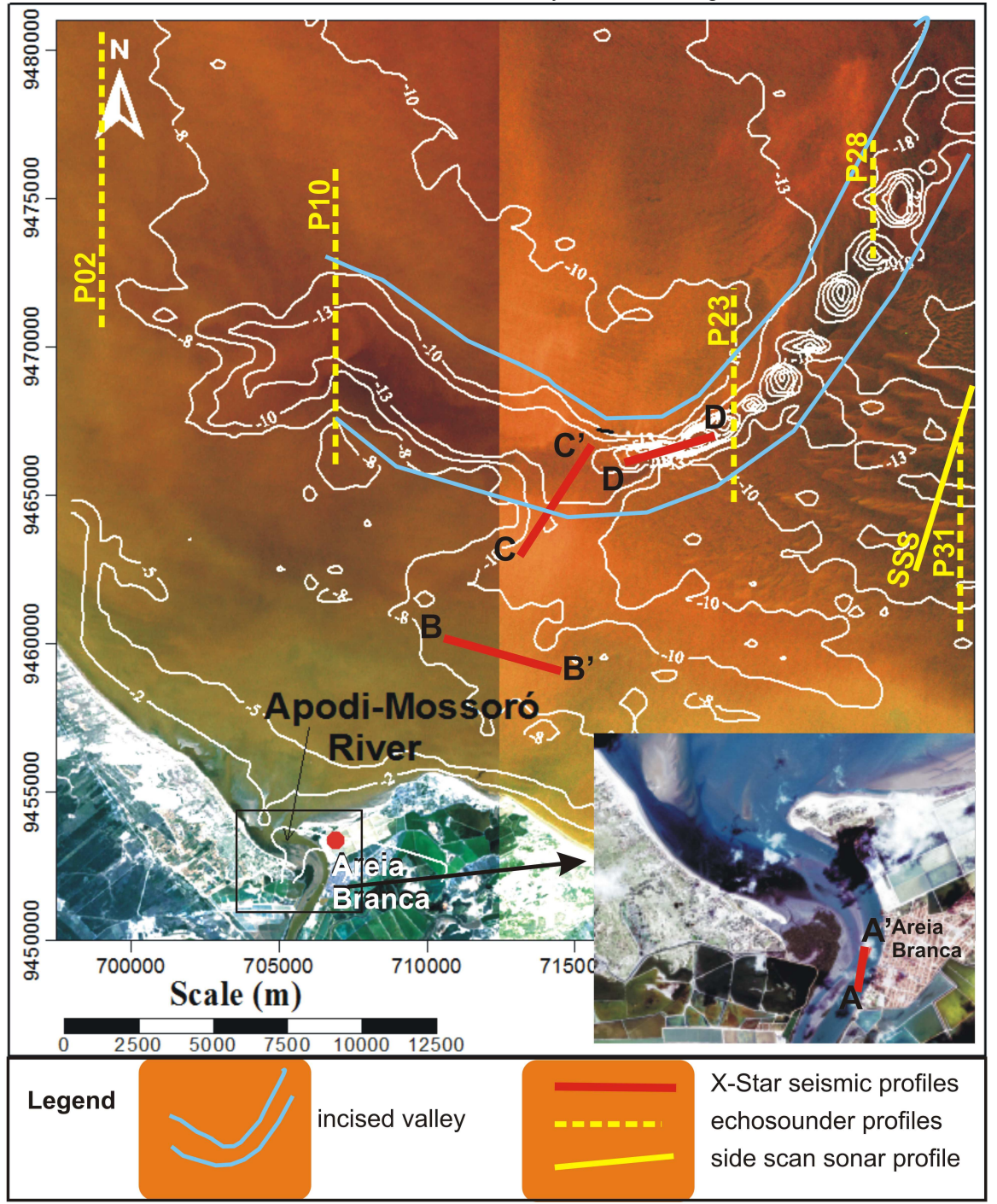

Fig. 3. Location of high resolution profiles discussed in the text superimposed on a Landsat 7ETM image. Echosounder profiles (P02, P10, P23, P28, P31) are represented by dashed yellow lines, side scan sonar profile (SSS) by a continuous yellow line and seismic profiles (A-A', B-B', C-C', D-D') by red lines. 


\section{Regional Setting \\ Geological setting}

The Apodi-Mossoró Estuary and incisedvalley, located in the northern portion of the Rio Grande do Norte State, is one of the most important river systems that flow into this part of the Brazilian Continental Shelf: a Tertiary mixed siliciclastic-carbonate platform of the Potiguar basin (Fig. 1) at shallow water depths down to $60 \mathrm{~m}$. The Potiguar Basin is part of the NE Brazilian Cretaceous rift system (MATOS, 1994) and one of the primary Brazilian oil producing fields exploited onshore.

The Potiguar Basin has undergone a complex evolution, merging elements of both the Equatorial and Southern Atlantic tectonic zones. From the Oligocene to recent times, the Potiguar Basin has been subjected to E-W compression, which has been released along pre-existing fault lines lying approximately NE-SW (MILANI; THOMAZ- FILHO, 2000). As a result, this is the most seismically active region of Brazil. The shelf configuration is strongly affected by vertical movements along these faults. Dunes, ebb tidal deltas, beachrocks, barrier islands and spits are present along the northern coast. It is a mixed-energy complex of wave-dominated and tidedominated coast.

The stratigraphic column of the Potiguar basin consists of both continental rift and marine postrift sediments. Deposition was determined by structures with a northeasterly trend during the rift phase in the Middle and Late Cretaceous, producing the valley's present geometry. Two major formations outcrop in this region: the Açu Formation, which is a clastic unit formed by an Albian -Turonian (110-90 My) mega-cycle; and the Jandaíra Formation, which represents a shallow carbonate shelf overlying the former unit $(90-78 \mathrm{My})$. Neocene sedimentary sequences of the offshore portion are composed of three lithostratigraphic units known, respectively, as the Tibau Formation (sandstones and conglomerates), the Guamare Formation (limestone), and the Ubarana Formation (marine shale). These units were built up during the upper part of a large regressive cycle, starting in the Late Campanian (78 My) and lasting through to the Holocene. They form a seaward thickening coastal-shelf-slope-basin system (PESSOA -NETO, 2003).

\section{Climate and Oceanographic setting}

The climate of the area is warm and seasonally semi-arid tropical. The coast is exposed to the continuous action of the northeasterly to easterly trade winds, which drive the longshore coastal drift and the transport of coastal sands from E to W-NW. Wind speed reaches a maximum of $9 \mathrm{~m} \mathrm{~s}^{-1}$ in August and a minimum of $4 \mathrm{~m} \mathrm{~s}^{-1}$ in April near São Bento do Norte (TABOSA et al., 2001), but can attain $18 \mathrm{~m} \mathrm{~s}^{-1}$ in August near the Açu river mouth (CHAVES et al., 2006).

The area is subject to a semi-diurnal mesotidal regime, with a maximum tidal range of 3.3 $\mathrm{m}$ and $1.2 \mathrm{~m}$, respectively, during spring and neap tides. The presence of small ebb-tidal deltas along the barrier island-spit system and at river mouths, as well spits perpendicular to the coast, show the strong influence of tides (VITAL, 2005). Waves measured nearshore have an average height of $56 \mathrm{~cm}$, with minimum and maximum heights of $27 \mathrm{~cm}$ and $123 \mathrm{~cm}$, respectively. In the breaker zone, the wave height generally has a maximum of $80 \mathrm{~cm}$ and a minimum of $22 \mathrm{~cm}$ (LIMA et al., 2006; CHAVES et al., 2006). The predominant currents are directed towards the westnorthwest. Offshore the maximum current speed is from about $10 \mathrm{~cm} \mathrm{~s}^{-1}$ during neap conditions to about $40 \pm 5.9 \mathrm{~cm} \mathrm{~s}^{-1}$ during spring tides, while nearshore current speeds are less variable and less intense $\left(20 \pm 4.2 \mathrm{~cm} \mathrm{~s}^{-1}\right)$. However, nearshore tidal current speeds measured locally near spits reach more than 50 $\mathrm{cm} \mathrm{s}^{-1}$.

\section{Seafloor Morphology}

The northern Rio Grande do Norte shelf is narrow, shallow, and faces the open ocean (Fig. 2). The continental shelf averages $40-45 \mathrm{~km}$ in width, and its edge is about $50-60 \mathrm{~m}$ deep. It has irregular morphology, with a mean gradient of around 1:1000. The shelf plunges seawards in a steep slope with a gradient of up to 1:11 (VITAL et al., 2008).

A variety of bedforms ranging from tens of centimeters to kilometers in scale are present on this shelf. Six distinctive seabed features were recognized to the east by Vital et al. (2008): (I) very large longitudinal dunes, (II) very large transverse dunes, (III) small dunes, (IV) isolated shallow marine sandy bodies, (V) submerged beachrock chains, and (VI) incised-valley systems.

\section{Relative Sea-level Changes}

In the Rio Grande do Norte region (NE Brazil), the sea level lowstand during the last glacial maximum (LGM), $\sim 20,000$ cal. yrs. BP, is calculated at $107 \mathrm{~m}$ below the present sea level (PELTIER, 1998). The Holocene sea-level history of the mesotidal northern Rio Grande do Norte area has been reconstructed by Caldas et al. (2006) and Stattegger et al. (2006) from sedimentology and AMS radiocarbon dating of beachrock and tidal lagoonal sediments. According to these authors, the post-glacial marine transgression (PMT) occurred from $\sim 3 \mathrm{~m}$ to $7000 \mathrm{cal}$. yrs. BP and passed the modern sea level $6700 \mathrm{cal}$. yrs. ago. The Holocene highstand reached $1.3 \mathrm{~m}$ above modern sea level at $5900 \mathrm{cal}$. yrs. BP as determined by 
beachrock samples from the uppermost part of an intertidal foreshore deposit. A 5700 cal. year old shell midden overlies this beachrock, that represents the spring-tide sea level. It was only after the highstand that the sea level dropped to its present position.

\section{Results AND Discussion}

\section{General Geomorphology}

Through satellite image analysis it was possible to identify well marked features and bedforms on the continental shelf offshore of the Apodi-Mossoró Estuary (Fig. 4). Correlating the images processed with the bathymetrical model (Figs 2 to 5), it was possible to recognize four main geomorphological features (Figs 4 and 5): 1) flat bottom, 2) incisedvalley, 3) reefs, and 4) subaqueous dunes. The subaqueous dunes were classified in accordance with Ashley (1990).

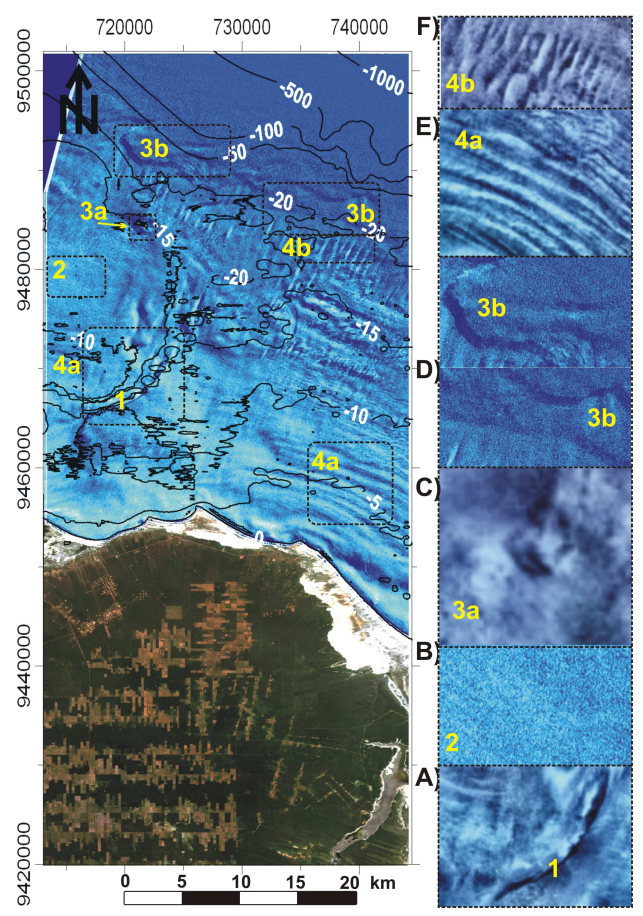

Fig. 4. Satellite Landsat Image showing the four main seabed features and bedforms that occur in the study area (yellow numbers). A) incised-valley; B) flat bottom; C) isolated reef; D) linear reefs; E) very large longitudinal dunes; F) very large transversal dunes.

Flat Bottom: Patterns showing the existence of sedimentary bedforms alternate with an essentially flat and featureless seabed, as indicated by the absence of tonal contrast on the satellite image (Figs 3 and 4).
This variability can be interpreted as an indicator of a spatially variable, dynamic environment and as an indicator of an environment with variable sediment character. Bathymetric profiles indicated a gentle slope with gradient variation from 1:1700 nearshore, to 1:20 000 offshore (Figs 2, 3, 4 and 5A). Because the inner shelf is extremely flat, its depth gradient is gentle. The flat bottom was probably formed of bioclastic sediments, or because of insufficient energy (hydrodynamic conditions) to form other features.

Incised - valley: The Apodi - Mossoró incised-valley (Figs 2, 3, 4 and 5) is of about $30 \mathrm{~km}$ in length. It lies in two main directions: NW-SE nearshore $(5 \mathrm{~km} \mathrm{-}$ maximum width and $3 \mathrm{~km}$ - medium width), and NESE offshore $(1.4 \mathrm{~km}$ - medium width). The channel direction of the incised valley. The southern flank of the nearshore channel (NW-SE direction) is steep, and probably represents a residual scarp of the neotectonic reactivation of ancient faults (in Stewart and Hancock's sense, 1990), with a gradient of 1:150 (Fig. $5 \mathrm{~B})$. On the other hand, the northern flank is more gentle, presenting different step levels (or terraces), each with a gradient of 1:400. An off-shore cross section (NE-SW direction) shows that the channel becomes narrower with symmetrical and steeper slopes (downcut V-shaped), with a gradient of 1:30 (Fig. 5C); the difference between the seafloor depths amounts to $30 \mathrm{~m}$.

Reefs: Reefs are observed in the eastern portion of the area (Fig. 4C), along the $-20 \mathrm{~m}$ isobaths (Fig. 4D) and next to the channel margin (Fig. 5D). They appear as abrupt, raised features on the seabed and are classified as linear or isolated or as organic and inorganic (SANTOS et al., 2007). Both linear and isolated reefs were observed in the study area.

Isolated reefs are to be found in the eastern portion of the area (Fig. 4C) or are present preferentially on the submarine channel's margins (Fig. 5d). They have either a convex or a flat top and are about 8 to $12 \mathrm{~m}$ in height and from 30 to $300 \mathrm{~m}$ wide. They usually occur at up to $12 \mathrm{~m}$ depth, but close to the channel margin. Bathymetric records of isolated reefs show that they usually occur at up to 12 $m$ depth (Fig. 4C), but near the channel margin they can reach up to $20 \mathrm{~m}$ depth (Fig. 5d); these records also show that their flanks are vertical and abrupt. Samples collected by scuba diving indicated that coral fauna is present.

Linear reefs are located at around $20 \mathrm{~m}$ depth (Fig. 4D). These linear reefs rise to 2.5 to $5 \mathrm{~m}$ above the seafloor, and their width is of $500-1000 \mathrm{~m}$. On satellite images they present the same characteristics as the inorganic reefs described by Santos et al. (2007). This author classified the linear and inorganic reefs as sandstone banks, relating them to the beachrocks found on the coast. 
Subaqueous dunes: Very large dunes are found in the area, lying both longitudinally and transversally to the coast (Figs 3 and 4 ). The very large transversal dunes are restricted to depths between 15 and $30 \mathrm{~m}$ (outer shelf), while the longitudinal ones are in water shallower than $15 \mathrm{~m}$ (inner shelf). In general, the dune crests of the three-dimensional very large longitudinal dunes lie parallel to the coastline. Dune heights attain $5 \mathrm{~m}$, and their widths vary from 400 to $600 \mathrm{~m}$ (Fig. $5 \mathrm{E})$. These dunes are of $200 \mathrm{~m}$ to $1.5 \mathrm{~km}$ in length and in some cases, there is an abrupt westerly flank, which indicates a sediment remobilization by the ebb tide currents. In the side scan sonar profile (Fig. 5F), the subaqueous dunes are represented by different color bands. These bands correspond, respectively, to the dune crests and troughs. The color and the reflection coefficient, calibrated with samples collected in situ, indicate that the crests are composed mainly of siliciclastic sands (carbonates < 30\%), better sorted and finer grained than those of the troughs.
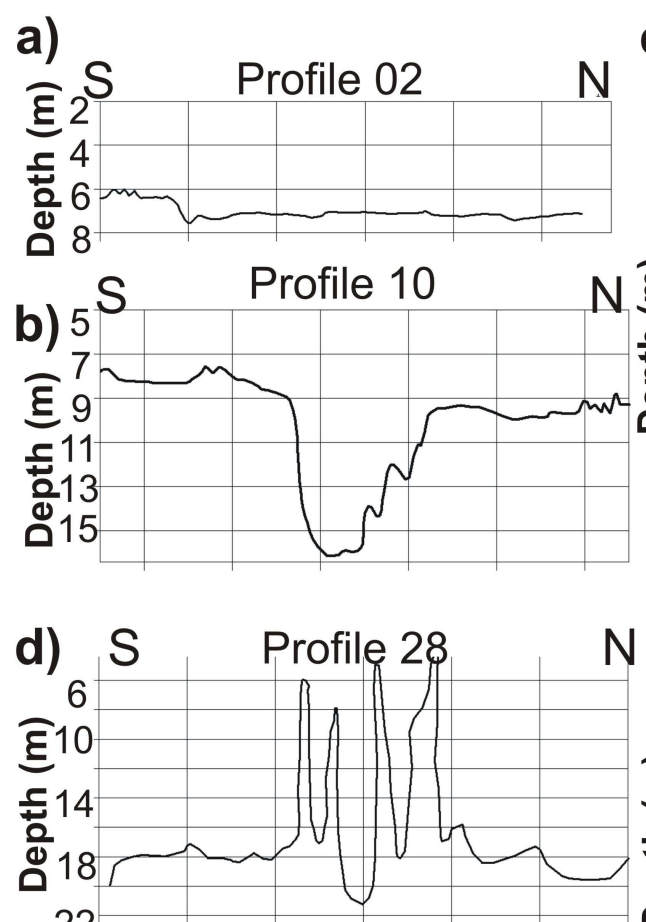

c) $\mathrm{S}$ $\mathrm{S}$

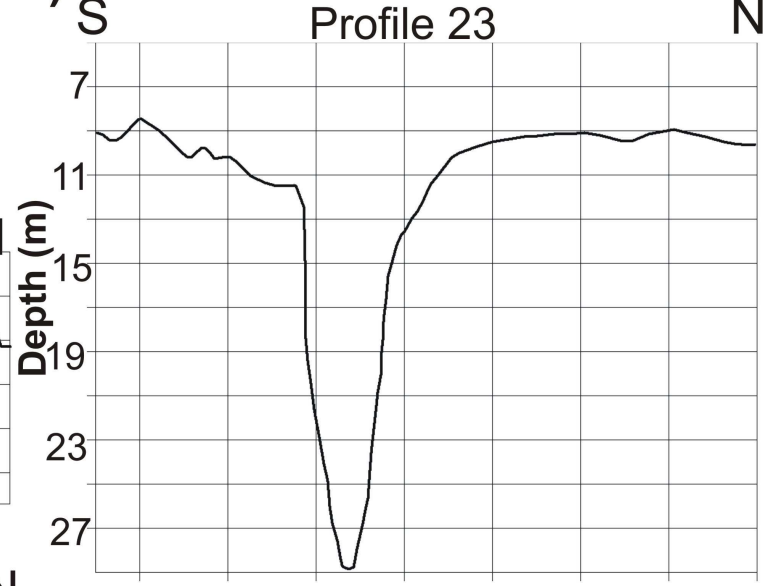

\section{e)}
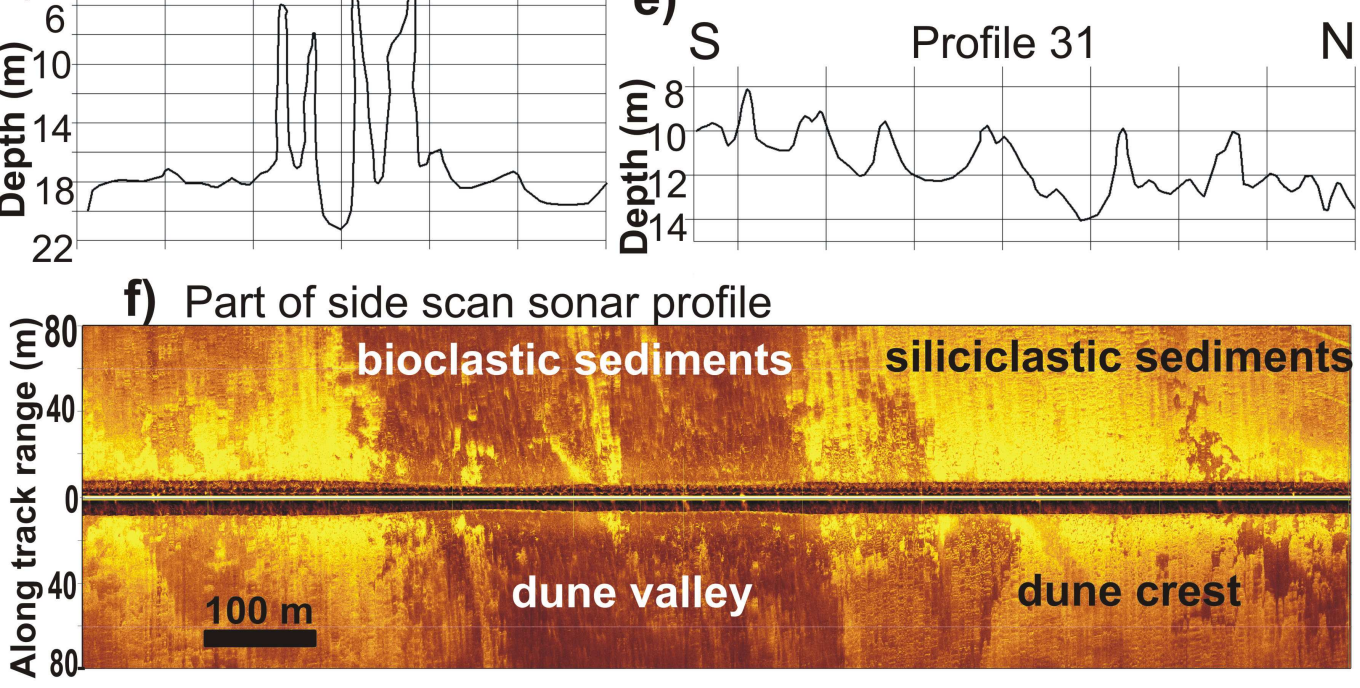

Fig. 5. Part of bathymetric profiles (for location see Fig. 3). a) flat bottom in the western part of the area; b) part of the bathymetric profile NW-SE of the channel, showing a gentle incision; c) part of bathymetric profile NE-SW of the channel with deep incision; d) linear reefs; e) subaqueous dunes located on the east side of the submarine channel, and f) part of side scan sonar profile showing the difference in sediment composition between valley and crests (bandwidth $500 \mathrm{kHz}$ and $80 \mathrm{~m}$ range). Modified from Lima and Vital (2006). 
The hydrodynamic data indicate that the direction of the flow has an ESE-WNW component associated with the tide regime (LIMA; VITAL, 2006). During flood tide, the current propagates towards a $<300$ degree compass bearing, with a magnitude varying from $20 \mathrm{~cm} / \mathrm{s}$. During ebb tide, the flow changes direction to a $>100$ degree compass bearing, with its greatest velocities reaching $30 \mathrm{~cm} / \mathrm{s}$. This difference in current speed is probably due to the change of the cycle from neap to spring tide. That is observed for the $1 \mathrm{~m}$ rise in sea-level. According to Lima and Vital (2006) the maximum intensity of the currents $(37 \mathrm{~cm} / \mathrm{s})$ observed during the period recorded is incapable of transporting great amounts of sediment, and the hypothesis that currents formed these dunes by sediment transport is improbable. However, they can justify this by pointing to the possible remobilization of these sediments and low ESE-WNW transport, as in the longshore drift direction.

\section{Seismic-stratigraphy}

Four representative seismic profiles show the Pleistocene-Holocene stratigraphy observed in the study area. Profile A-A' represents the main channel of the Apodi-Mossoró Estuary, opposite Areia Branca city (Fig. 6), Profile B-B' the nearshore parallel to the coast, between 5-10 m depth (Fig. 7), Profile CC'(Fig. 7) crosses the incised valley and D-D'(Fig. 9) follows it. Five features are easily recognized on the recorded profiles: 1) a prominent reflector, called Horizon 1;2) tableau structure; 3) incised channels; 4) oblique seismofacies, and 5) parallel seismofacies.

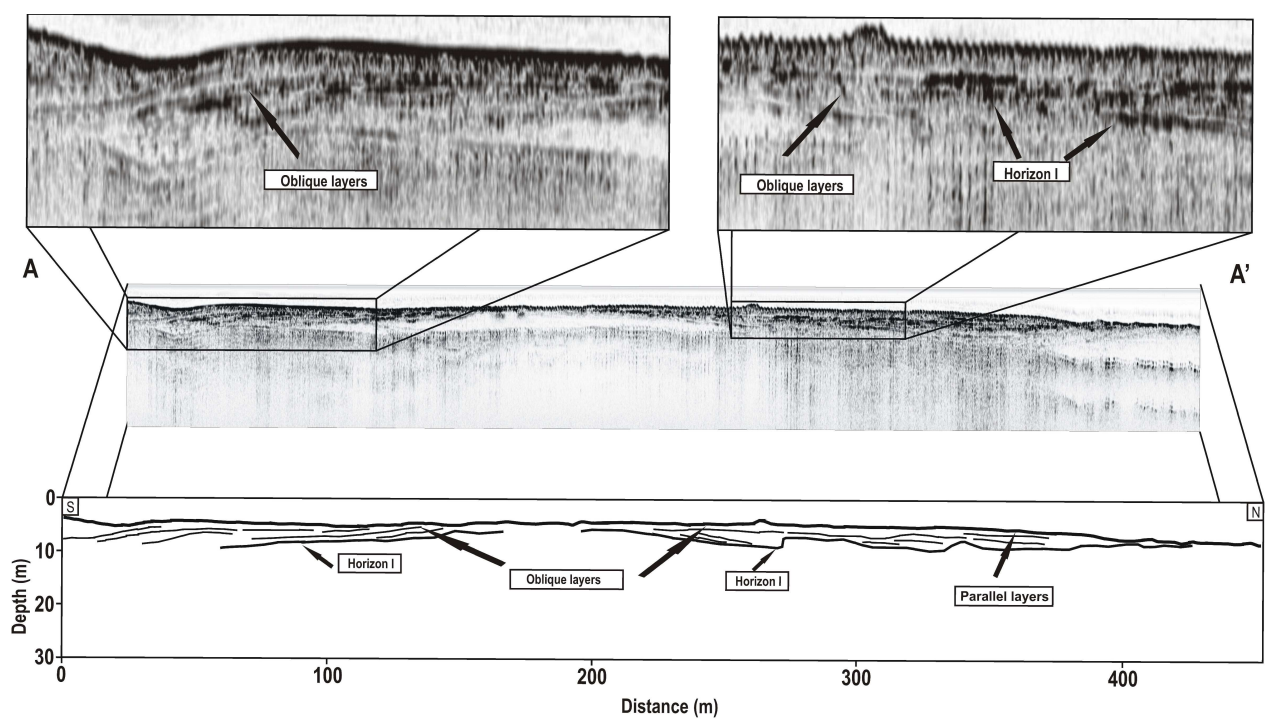

Fig. 6. Part of Profile A-A' taken along the main channel of the Apodi-Mossoró Estuary. For location see Figure 3.

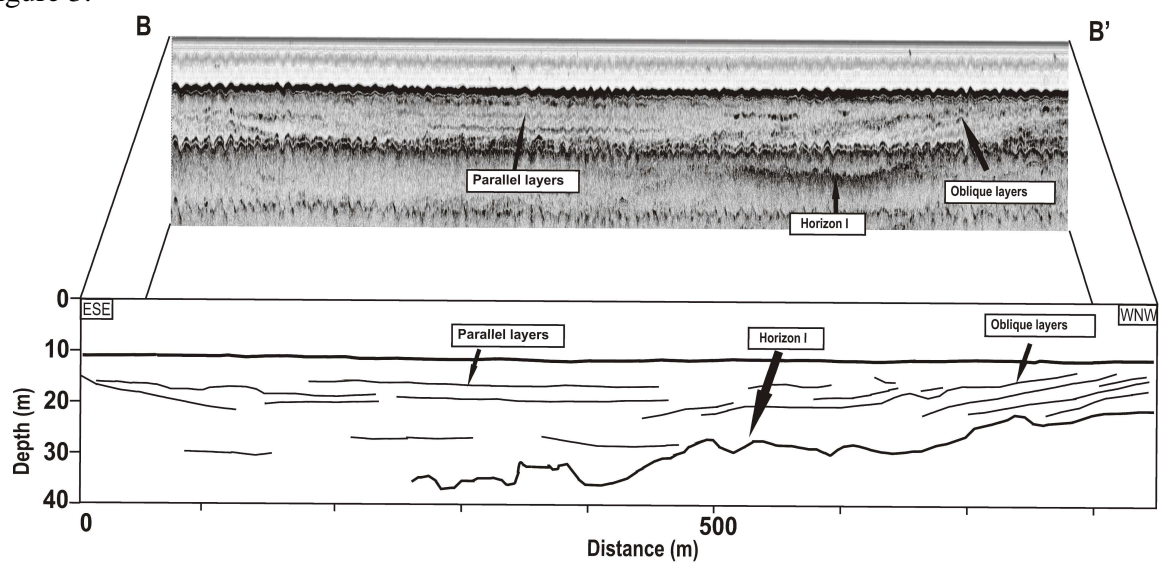

Fig. 7. Part of Profile B-B' taken nearshore parallel to the coast. For location see Figure 3. 
Horizon I: The most prominent seismic surface is represented by Horizon I, present continuously in all the profiles, except when the signal is lost. Horizon I can also be observed in the main channel of the ApodiMossoró Estuary (Profile A-A', Fig. 6) showing that this inconformity can be traced from the present-day river out onto the shelf. Within the estuary (Fig. 6) the horizon is situated between 5 and $10 \mathrm{~m}$ depth, as related to the present river level. On the shelf (Figs 7 to 9), this horizon is situated at up to $40 \mathrm{~m}$ depth, when the older sediments are incised with a typical cut and fill structure geometry (Fig. 9).

Tableau feature: A tableau-like feature (Fig. 9), characterized by strong reflections, is $200 \mathrm{~m}$ in length and $8 \mathrm{~m}$ high. The tableau is entirely covered by young sediments. The sediments on both sides of the tableau present an inclination with a gradient of about $0.08^{\circ}$ (Fig. 9), probably indicating tectonic activity, and interpreted as an uplift which occurred in recent times, because of the sediment symmetry above Horizon I (Fig. 9).

Incised valleys: The seismic profiles show the presence of the incised valley throughout the area (Figs 6 to 9), probably cut in the last sea level fall during the late Pleistocene. The ancient ApodiMossoró River, as the Açu River (SCHWARZER et al., 2006), meandered within this incised valley, cutting into the shelf deposits and forming smaller incised valleys now represented by cut and fill features. These processes are indicative of an erosional surface during lowstand conditions as well as of changes in the sedimentation conditions in the ApodiMossoró River. According to Pessoa-Neto (1999, 2003), the incised-valley can be observed in this area since the Miocene.

Oblique seismofacies: This seismofacies may be observed in all the profiles (e.g., Figs 6 to 9) from the estuary out into the deeper parts of the valleys. In the cross sections it represents the progradational sediment deposition filling the incised-valley in a highstand system stretch (Fig. 8). Its low acoustic impedance contrast prevents any exact differentiation between the reflectors' terminations in the top and downlapping configuration. In sections along the incised valley clinoforms are clearly to be observed and it is evident that they dip towards the NE-E (Fig. 9), showing the filling progradational effect of the paleochannel during the Post Glacial Marine Transgression (PMT).

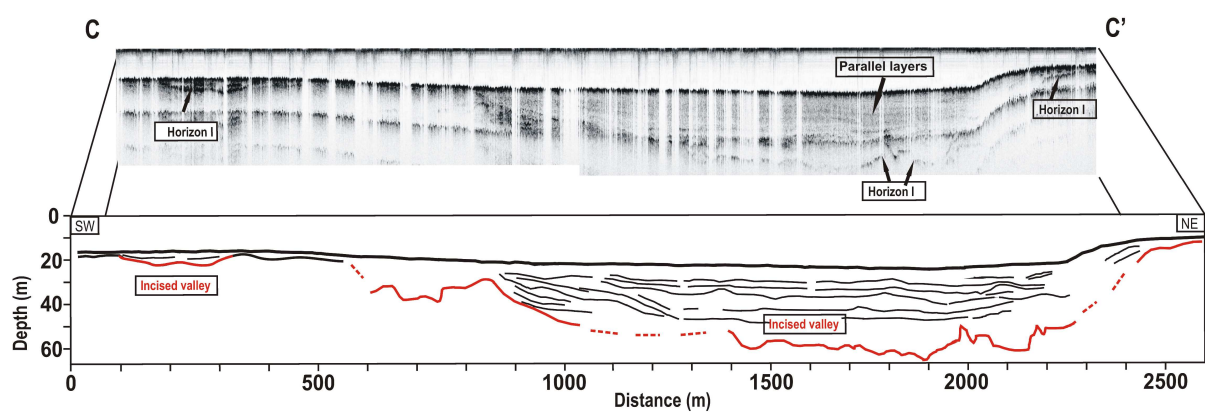

Fig. 8. Part of Profile C-C' taken offshore across the Apodi-Mossoró incised-valley. Red lines indicate the erosional valley itself, the strata that it eroded into (Horizon I is the seismic marker). For location see Figure 3.
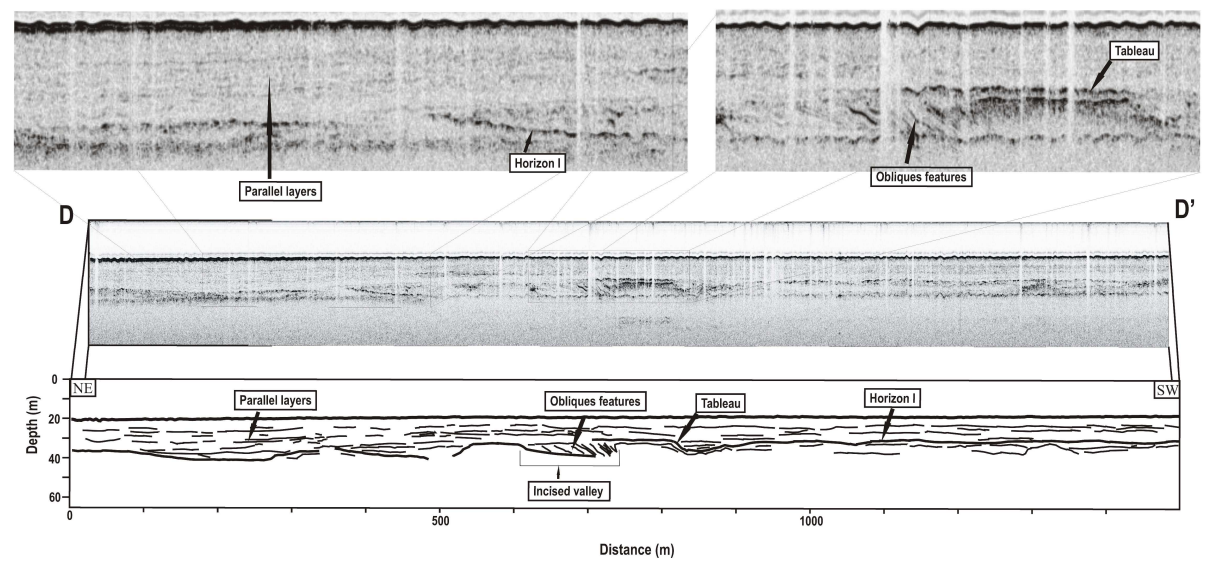

Fig. 9. Part of Profile D-D' taken along the Apodi-Mossoró incised-valley. For location see Figure 3. 
Parallel seismofacies: The parallel seismofacies are present mainly filling the incised-valleys (Figs 6 to 9), extending from the recent seafloor down to Horizon I. They are between 10 and $30 \mathrm{~m}$ thick filling the incised-valleys and overlying the tableau structures. In the incised valley, despite the low impedance contrast, the terminations of these layers seem to be in onlap. The sediments of this layer must have been deposited between the Holocene transgression and the present, with shelf aggradation and progradation. The aggradation occurred mainly inside the incised-valley, where there was enough space for sedimentation, but made the progradation sediment by-pass difficult.

Figure 10 provides a summary of the seismostratigraphic units identified in the ApodiMossoró area. Most of these are clearly developed on profile D-D' (Fig. 9). These units are numbered from I to IV, the numbering being from the uppermost (youngest) to the lowest (oldest).

Unit $I$ is defined as the parallel layers extending from the modern seafloor down to Horizon I. Unit II represents the oblique sediment sequence, which was recognized in the section of the valleyparallel profile (e.g., Fig. 9). The oblique features dip gently towards the north, and lie below Unit I but above Horizon I. Unit III encompasses the incised valley feature and Unit IV represents the tableau-like feature.

The above described seismofacies show that the continental shelf off Rio Grande do Norte has experienced regressive and transgressive stages during the Pleistocene and Holocene. Horizon I, observed in all the profiles, delineates the boundary between the sediments deposited after the Holocene transgression reached this area and the deposits formed during the Pleistocene. Schwarzer et al. (2006) also observed this same horizon in the continental shelf in front of the Açu river (east of the study area) and also attributed it to the Pleistocene/ Holocene limit.

Tableau-like features (Unit IV) were interpreted by Schwarzer et al. (2006) as pebble beds or consolidated sediments of the Barreiras and Tibau formation. These latter authors also affirm that such a tableau-like feature indicates the existence of recent tectonic activity resulting in the uplift which occurred during the Pleistocene or early Holocene because of the presence of Horizon I above this structure. Neotectonic activity in this area is closely related to the geometry of the basement structures. Ancient weakness zones were reactivated after the deposition of the Barreiras and Tibau formations. These zones have determined the general orientation of the ApodiMossoró valley (Pessoa- Neto, 2003).

The ancient Apodi-Mossoró River meandered within the incised valley, cutting into the shelf deposits and forming smaller incised valleys (Unit III). A careful analysis of the bathymetric data (Fig. 2), associated with the seismofacies, may suggest that an ancient river (or the ancient Apodi-Mossoró Mouth) could also have contributed to this incised Jshaped valley.

Oblique features (Unit II) are present at the transition between Horizon I and the overlying parallel layers of Unit I. According to Mitchum et al. (1977), a similar configuration of seismic reflectors is indicative of a sea level rise combined with low sediment supply, which permits topset beds to aggregate simultaneously with foreset progradation. In this case, such features would develop during sea level rises accompanied by a prograding shoreline. The features observed do not allow any distinction to be made between these scenarios if the oblique features are arranged within topset layering.

\section{Conclusions}

This study documents the evolution of a modern incised-valley infilling in a mixed tide and wave-energy coastal setting. The seafloor geomorphology and shallow stratigraphy of the northern Rio Grande do Norte continental shelf provide a record of sea-level change during the limit between the Pleistocene and Holocene periods and down to recent times.

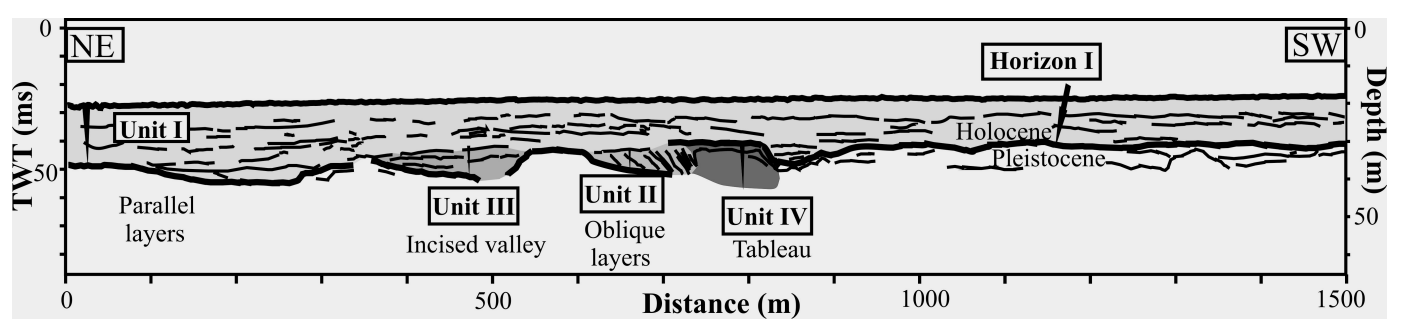

Fig. 10. Summary and interpretation of the seismostratigraphic units identified in the Apodi-Mossoró area. 
The Apodi-Mossoró incised valley is connected to the Apodi-Mossoró Estuary, nowadays with small sediment input. Four seismostratigraphic units and one Horizon were clearly identified in the Apodi-Mossoró Estuary \& incised-valley. They are numbered from I to IV, with the order of numbering being from the uppermost (youngest) to the lowest (oldest). Unit $\mathrm{I}$ is defined as the parallel layers extending from the seafloor down to Horizon I. Unit II represents the sigmoidal sediment sequence better recognized in valley-parallel profiles. Unit III represents the incised-valley feature and Unit IV the tableau-like structure. Horizon I was present in all profiles. These seismofacies found in the study area could be related to regressive and transgressive periods from the Pleistocene down to the present. During the last glacial maximum (LGM), around 20,000 B.P., when the sea level fell about $107 \mathrm{~m}$ below the current sea level and reached the shelf border (PELTIER, 1998), valleys were incised on the exposed shelf. During the Transgressive phase and Highstand system tract the valleys were filled (or partially filled) with Holocene sediments above Horizon I. Recent tectonic activities are evident, suggesting the uplift of this portion of the shelf.

\section{ACKNOWLEDGEMENTS}

We wish to thank the PRH-ANP 22 (Brazilian National Oil Agency) for the scholarship granted to S. F. L. Furtado and M. P. Gomes; and the $\mathrm{CNPq}$ for the productivity research grant, number $312275 / 2006-4$, awarded to H.Vital. Financial support for both field and laboratory work was provided by POTMAR-SISPLAT-PETRORISCO (REDE 05/FINEP/CTPETRO/ CNPq/ PETROBRAS), MARRN (FINEP/CTINFRA), UNIBRAL 21-04 (CAPES/DAAD). Thanks are also due to the GGEMMA and GEOPRO groups, specially to Pauletti, Miriam, Chico and Izaac for field assistance under adverse maritime conditions.

\section{REFERENCES}

ASHLEY, G. Classification of large-scale subaqueous bedforms: a new look at an old problem. J. sedim. Petrol., v. 60, p. 60-172, 1990.

BOYD, R.; DALRYMPLE, R. W.; ZAITLIN, B. A Estuarine and incised-valley facies models. In: POSAMENTIER, H. W.; WALKER, R. G. (Ed). Facies models revisited. Tulsa, Okla., 2006. (SEPM Spec. Publ., n. 84, p. 171-235).

CALDAS, L. H. O.; STATTEGGER, K.; VITAL, H. Holocene sea-level history ; Evidence from coastal sediments of the northern Rio Grande do Norte coast, NE Brazil. Mar. Geol., v. 228, p. 39-53, 2006.

CHAVES, M.; VITAL, H.; SILVEIRA, I. M. Beach morphodynamics of the Serra oil field, northeastern
Brazil. J. coast. Res., Special Issue 39, p. 594-597. 2006.

DALRYMPLE, R. W.; BOYD, R.; ZAITLIN, B. A. Incisedvalley systems: Origin and sedimentary sequences. Tulsa, Okla.: 1994. (SEPM Spec. Publ., n. 51, p. 0310).

DALRYMPLE, R.W.; LECKIE, D. A.; TILLMAN, R.W. Incised valleys in time and space. Tulsa, Okla., 2006. (SEPM Spec. Publ., n. 85).

LI, C.; WANG, P.; FAN, D.; YANG, S. Characteristics and formation of late Quaternary incised-valley-fill sequences in sediment-rich deltas and estuaries: case study from China. In: DALRYMPLE, R.W.; LECKIE, S. A.; TILLMAN, R.W. (Ed.). Incised valleys in time and space. Tulsa, Okla., 2006. (SEPM Spec. Publ., n. 85, p. 141-160).

LIMA, S. F.; VITAL, H. Geomorphological and paleogeographic characterization of continental shelf of the Apodi-Mossoró River, RN-Brazil. In: BREBBIA, C. A.. (Ed.). Environmental problems in coastal regions VI, including oil spill studies. Cambridge, GB: Wessex Institute of Technology; Cambridge Printing, Great Britain, 2006. p. 351-360.

LIMA, Z. M. C.; VITAL, H.; TABOSA, W.F. Morphodynamic Variability of The Galinhos Spit, Northeastern Brazil. J. coast Res., Special Issue, 39, p. 598-601, 2006.

LORING, D. H.; RANTALA, R. T. T. Manual for the geochemical analysis of marine sediments and suspended particulate matter. Earth-Sci. Rev., v. 32, p. 235-283, 1992.

MATOS, R. M. D. The northeastern Brazilian rift system. Tectonics, v. 1, p. $767-790,1994$.

MILANI, E. J.; THOMAZ- FILHO, A. Sedimentary basins of South America. In: CORDANI, U. G.; MILANI, E. J.; THOMAZ- FILHO, A.; CAMPOS D. A. (Ed). Tectonic evolution of South america. INTERNATIONAL GEOLOGICAL CONGRESS. 31., Rio de Janeiro, 2000. p. 389-449.

MITCHUM, R. M.; VAIL, P. R.; SANGREE, J. B. Seismic stratigraphy and global changes of sea level. Part 6: Stratigraphic interpretation of seismic reflection patterns in depositional sequences. In: PAYTON, C.E. (Ed.). Seismic Stratigraphy - application to hydrocarbon exploration. AAPG Memoir, n. 26, p. 117- 133, 1977.

PELTIER, W. R. Global glacial isostatic adjustment and coastal tectonics. In: STEWART, I., VITA-FINZI, C. (Ed.). Coastal Tectonics. Geol. Soc. London, 1998. (Special Publ. n. 146, p. 1-29).

PESSOA-NETO, O. C. Análise estratigráfica integrada da plataforma mista (Siliciclástica-Carbonática) do Neogeno da Bacia Potiguar, nordeste do Brasil. 244 p. 1999. Dissertação (Mestrado) - Rio Grande do Sul Federal University, Porto Alegre-RS.

PESSOA-NETO, O. C. Estratigrafia de Seqüências da Plataforma Mista Neogênicana Bacia Potiguar, Margem Equatorial Brasileira. Rev. Bras. Geociênc., v. . 33, p. 263-278, 2003.

SANTOS, C. L. A.; VITAL, H.; AMARO, V. E.; KIKUCHY, R. K. P. Mapeamento de recifes na plataforma continental. Nordeste do Brasil: Touros a Maracajau - RN. Brazilian J. Geoph., v. 1,p. 1-10, 2007. 
SCHWARZER, K.; STATTEGGER, K.; VITAL, H. BECKER, M. Holocene coastal evolution of the Rio Açu Area (Rio Grande do Norte, Brazil). J. Coast Res., Special Issue n. 39, p. 141-145, 2006.

STATTEGGER, K.; CALDAS, L. H. O.; VITAL, H. Holocene coastal evolution of the Northern Rio Grande do Norte Coast, Brazil. J. Coast. Res., Special Issue n. 39, p. 151-156, 2006.

STEWART, I. S.; HANCOCK, P. L. What is a fault scarp? Episodes, v. 13-4, p. 256-263, 1990.

TABOSA, W. F.; LIMA, Z. M. C.; VITAL, H.; GUEDES, I. M. G. Monitoramento costeiro das praias de São Bento do Norte e Caiçara do Norte - NE Brasil. Rev. Pesq. Geoc., v. 28, p. 383-392, 2001.

VITAL, H. Erosão e progradação no litoral do Rio Grande do Norte. In: MUEHE, D. (Org.). Erosão e progradação do litoral brasileiro. Brasilia, DF: Ministério do Meio Ambiente, p.159-176, 2005.
VITAL, H.; STATTEGGER, K.; AMARO, V. E.; SCHWARZER, K.; FRAZÃO, E. P.; TABOSA, W. F. Inner continental shelf off northern Rio Grande do Norte, NE Brazil: A modern high-energy siliciclasticcarbonate platform. In: HAMPSON, G., DALRYMPLE, R. (Ed.). Recent advances in shoreline -shelf Stratigraphy. Tulsa, Okla., 2008. (SEPM Special Issue n. 90).
(Manuscript received 03 June 2009; revised 27 November 2009; accepted 21 May 2010) 